\title{
The Heterogeneity of the Developing Brain Insulin Receptor ${ }^{1}$
}

\author{
S. DEVASKAR, L. HOLTZCLAW, AND F. SADIQ \\ Division of Neonatology, Department of Pediatrics, St. Louis University and The Pediatric Research Institute, \\ Cardinal Glennon Children's Hospital, St. Louis, Missouri 63104
}

\begin{abstract}
Comparison of the adult brain insulin receptor (IR) to other tissue IR demonstrates that the former migrates $\sim 10 \mathrm{kD}$ faster on sodium dodecyl sulfate-polyacrylamide gel electrophoresis due to deficient sialic acid content of the asparagine $\mathrm{N}$-linked carbohydrate moieties. We studied these receptors in the fetal rat (18-day) brain $(\sim 125 \mathrm{kD})$ and liver $(\sim 135 \mathrm{kD})$, and demonstrated that similar differences are present during fetal life. These differences are not modified by hyperglycemia associated with both mild hyperinsulinemia and normoinsulinemia/ hypoinsulinemia. We further studied the specific brain cell types: neurons, glial cells, and purified microvessel preparation, and demonstrated a heterogeneity in the $\mathrm{N}$-linked glycosylation of the IR within an organ (brain). The neuronal $(\sim 125 \mathrm{kD})$ and microvascular $(\sim 125 \mathrm{kD}, \sim 135 \mathrm{kD})$ IR are deficient in sialic acid, thus conferring neuraminidase-insensitivity to the whole brain, whereas the glial cell IR, similar to the liver IR, exhibits neuraminidase sensitivity and migrates intermediate $(\sim 128 \mathrm{kD})$ to the liver and brain IR. The functional significance of this receptor heterogeneity between various tissues and cells within the same organ (brain) remains to be determined. (Pediatr Res 24:683-692, 1988)
\end{abstract}

Abbreviations

IR, insulin receptor

kD, kilodaltons

SDS-PAGE, sodium dodecyl sulfate-polyacrylamide gel electrophoresis

The IR, a heterotetrameric glycopeptide composed of two $\alpha$ and two $\beta$-subunits linked by disulfide bonds, mediates the biologic effects of insulin (1). In the brain of both the adult (2) and developing animal (3-5), insulin and insulin receptors have been demonstrated. These brain IR are unique in the sense that they do not down-regulate in response to high insulin concentrations $(5,6)$, a phenomenon that has been observed in various fetal neural $(5,7)$ and nonneural tissues as well $(8-10)$. There is evidence to support the fact that insulin is synthesized within the brain $(11,12)$ as well as the fact that circulating insulin traverses the blood-brain barrier and gains access to the brain (13), suggesting a dual origin for insulin within the central nervous system. Biologic effects of insulin, akin to those in other tissues such as

Received January 21, 1988; accepted August 2, 1988.

Correspondence Sherin U. Devaskar, M.D., Cardinal Glennon Children's Hospital, 1465 South Grand Boulevard, St. Louis, MO 63104.

Supported in part by grants from the Monsanto/Searle Research Funds and the Fleur de Lis Foundation, St. Louis, MO.

'Parts of this work were presented in preliminary form at the Mid West Society 1987 and Society for Pediatric Research 1988. metabolic (14) and growth-promoting effects (15), have been demonstrated within the brain, specifically in glial cells; whereas the unique effect of neuromodulation has been observed only in neuronal cells $(16,17)$.

Structural studies of the adult brain IR in comparison with the IR of adipocytes and liver have revealed a heterogeneity. Specifically, the $\alpha$-subunit which binds to the ligand has been demonstrated to be $\sim 10 \mathrm{kD}$ lighter in the brain than in other tissues $(7,18-20)$. Recent evidence supports the fact that a decrease in the sialic acid content of the brain IR N-linked carbohydrate moieties is responsible for this heterogeneity $(21$, 22 ). We studied this heterogeneity in the fetal rat to determine whether these structural IR differences are present developmentally as well. Additionally, we investigated the effect of hyperglycemia along with either mild hyperinsulinemia or normo/hypoinsulinemia on the $\mathrm{N}$-linked glycosylation of the fetal and adult brain and liver IR ( $\alpha$-subunit) to determine whether there was any association between the IR structure and its ability either to down- or up-regulate in response to varying insulin concentrations, as previously observed (5-10).

We further studied the structure of the $\alpha$-subunit of the IR in specific brain cell types such as the neurons, glial cells, and purified microvessels to investigate whether a heterogeneity in the structure of the IR determined the previously reported differential biologic effect of the hormone in the various cell types $(14-17,23)$.

\section{MATERIALS AND METHODS}

Animals. Two different species were used. The rat was used for the in vivo experiments in order to produce fetal hyperglycemia with small volumes of maternal glucose infusates $(24,25)$. The New Zealand White rabbit was preferred over the rat for isolation of brain cells as the yield was significantly better than in the rat, and the rabbit brain cell types have been extensively characterized previously by us (11).

Characterization of $I R \alpha$-Subunit. Sprague-Dawley adult nonpregnant and fetal rats (18-day; term, $\sim 21$ days) were anesthetized with pentobarbital and their livers and brains excised. Tissues from an individual adult animal and pooled fetuses of a litter were homogenized and crude membranes prepared by differential centrifugation, as described previously (19). The protein content was determined by the Biorad assay (26) and these membranes used in the experiments designed to compare the fetal IR to the adult.

Diabetic model. Maternal diabetes was induced in 12-day pregnant rats by intraperitoneal injections of streptozotocin $(60$ $\mathrm{mg} / \mathrm{kg}$ ). Controls received saline injections alone. On day 20 of gestation, maternal and pooled fetal brain and liver membranes were prepared (19). These membranes were used in experiments designed to study the effect of hyperglycemia along with normoinsulinemia/hypoinsulinemia on the fetal and adult rat brain and liver IR. 
Surgical model. To study the effect of hyperglycemia associated with mild hyperinsulinemia on the fetal and adult rat brain and liver IR, 13-day pregnant rats were given pentobarbital anesthesia and underwent cannulation of their external jugular vein. The procedure lasted 15 to $20 \mathrm{~min}$, and the animals recovered soon after skin closure. The animals were moving freely in their cages and were allowed to recover from the stress of surgery for $24 \mathrm{~h}$, after which some rats received $30 \%$ glucose water infusion at a $17 \mathrm{mg} / \mathrm{kg} / \mathrm{min}$ rate; controls received a similar rate of sterile distilled water infusion until the rats were 18 days gestation. Both groups of animals were allowed free access to water and food. This previously described animal model results in fetal hyperglycemia and mild hyperinsulinemia $(24,25)$. Eighteen-day gestation maternal and pooled fetal brain and liver membranes were prepared as stated above.

Maternal and fetal plasma was collected for glucose and insulin concentration determinations (5) from both the diabetic and surgical models and their respective controls.

Rabbit Brain Cell Preparations. Brain microvessel-enriched tissue fraction was prepared and characterized as described before (27). The purity of the preparation was determined by the percentage recovery of the alkaline phosphatase enzyme activity when compared to the crude homogenate (27) and the contamination by cellular components (neurons and glia) determined by phase contrast microscopic examination of the final preparation.

Cell culture. Neuron-enriched and glial cell cultures were prepared from 10-day-old neonatal rabbits and characterized as previously described (11). The individual cell types were washed extensively with ice-cold Hepes buffer $(50 \mathrm{mM}$ Hepes, $2 \mathrm{mM}$ phenylmethylsulfonyl fluoride, $10^{3} \mathrm{U} /$ liter aprotinin, $2 \mu \mathrm{M}$ pepstatin, $2 \mu \mathrm{M}$ leupeptin, $0.1 \mathrm{mg} / \mathrm{ml}$ bacitracin, $\mathrm{pH} 7.4)$ and scraped with a rubber policeman. The cell suspensions and the microvessel-enriched preparation were homogenized and centrifuged (20). The crude membrane pellet was used after protein estimation for characterization of the IR.

${ }_{125}$ I-Insulin Binding Assay. Porcine insulin (Eli Lilly Co., Indianapolis, IN) was iodinated as previously described (28) to a specific activity of 100 to $150 \mu \mathrm{Ci} / \mu \mathrm{g}$ and used as the ligand. $\sim 5$ $\times 10^{6} \mathrm{cpm}$ of ${ }^{125} \mathrm{I}$-insulin (used within a week of iodination with a trichloroacetic acid precipitability of $>95 \%$ ) was incubated overnight at $4^{\circ} \mathrm{C}$ in the presence (nonspecific) and absence of 1 $\times 10^{-6} \mathrm{M}$ native insulin along with $400 \mu \mathrm{g}$ of membrane protein, $35 \mu \mathrm{g}$ of aprotinin, and $1 \%$ bovine serum albumin in a final volume of $0.35 \mathrm{ml}$ of Hepes buffer, $\mathrm{pH}$ 7.8. The bound fraction was separated from the free fraction by centrifugation. The ${ }^{125} \mathrm{I}-$ insulin that bound to the receptor was cross-linked with $0.1 \mathrm{mM}$ disuccinimidyl suberate (29) as previously described.

Enzyme Studies. The cross-linked ${ }^{125}$-insulin-bound receptor complex was incubated with specific enzymes such as neuraminidase $(0.8 \mathrm{U})$, endoglucosidase $H(0.23 \mathrm{IU})$, endoglucosidase $\mathrm{F}$ $(10 \mu 1)$ or an equal volume of HEPES buffer (control) at $37^{\circ} \mathrm{C}$ (pH 6.0) for $2 \mathrm{~h}(30-32)$. The excess enzyme was removed by extensive washing, and the final pellet solubilized in Laemmli's buffer before subjecting the samples to SDS-PAGE and autoradiography (33).

\section{RESULTS}

Figure 1 demonstrates the adult rat liver $\alpha$-subunit of the IR specifically displaced by native insulin to possess an Mr of $\sim 135$ $\mathrm{kD}$. The neuraminidase enzyme digestion experiments demonstrating the cleavage of sialic acid moieties from the N-linked carbohydrates is shown in Figure 2A. Both the adult and fetal liver IR migrated $\sim 10 \mathrm{kD}$ higher than the respective brain IR $(\sim 125 \mathrm{kD})$. The fetal and adult liver IR mobility enhanced following the neuraminidase treatment, whereas the brain IR remained unchanged. After neuraminidase treatment, neither the adult nor fetal liver IR $(\sim 130 \mathrm{kD})$ co-migrated with the control adult and fetal brain IR $(\sim 125 \mathrm{kD})$, suggesting the absence (or deficiency) of other $\mathrm{N}$-linked carbohydrate moieties
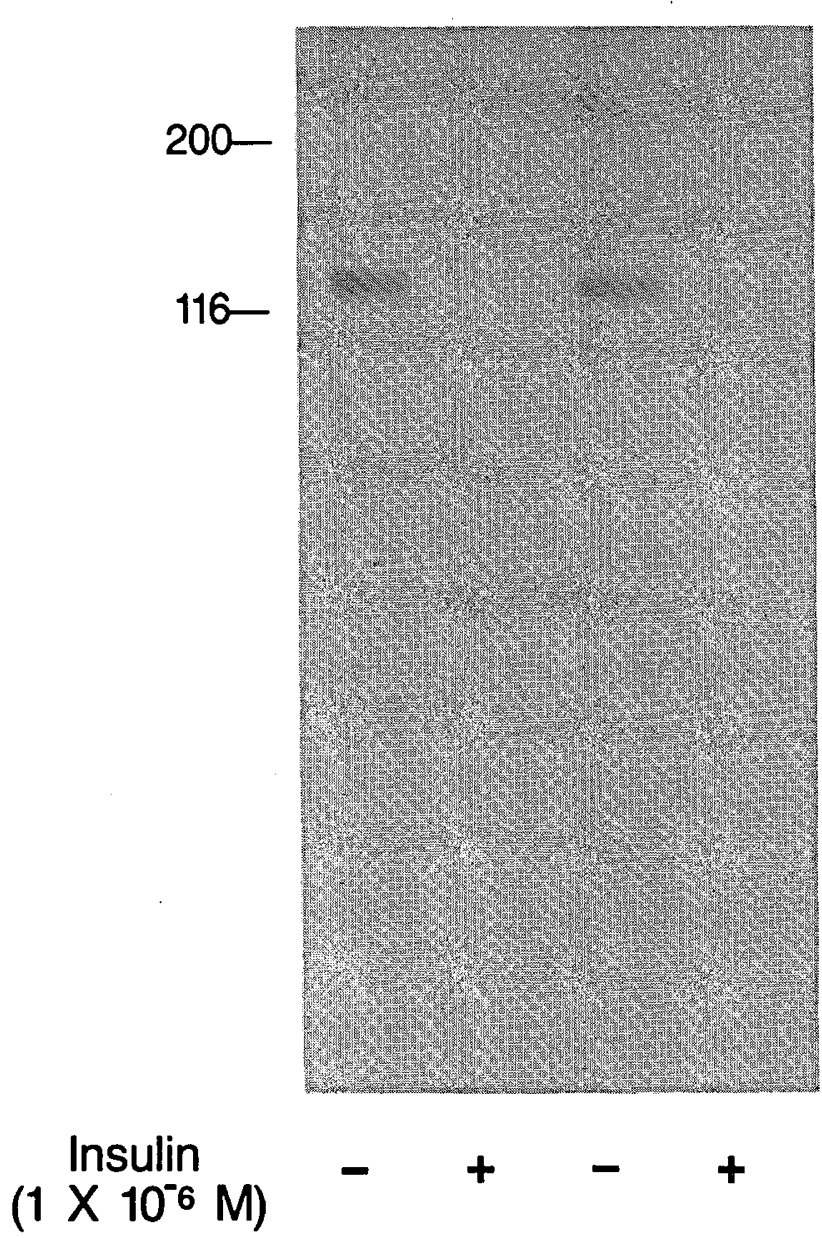

Fig. 1. Autoradiographs SDS-PAGE demonstrating the ${ }^{125} \mathrm{I}$-insulin cross-linked receptor: adult liver insulin receptor ( $\alpha$-subunit) with an $\mathrm{Mr}$ of $\sim 135 \mathrm{kD}$. A total of $1 \times 10^{-6} \mathrm{M}$ unlabeled insulin specifically displaced the labeled hormone from the receptor.

besides sialic acid. Endo $\mathrm{H}$ (cleaves the high mannose carbohydrate residues) enhanced the mobility of the adult and fetal liver and brain IR to the same extent (Fig. 2B). Again, after the enzyme treatment, the liver IR did not co-migrate with the control adult and fetal brain IR, suggesting other carbohydrate moieties, such as sialic acid, to be responsible for this discrepancy between the two organs. By contrast, Endo F (cleaves both the $\mathrm{N}$-linked complex oligosaccharides and the high mannose carbohydrate residues) enhanced the mobility of the adult and fetal liver and brain IR, so that all the posttreated IR comigrated (Fig. $2 C$ ), implying that both the high mannose and complex oligosaccharide residues are similar in the two organs.

Streptozotocin treatment resulted in maternal and fetal hyperglycemia along with hypoinsulinemia in the former and normoinsulinemia in the latter, whereas maternal infusions of glucose, while producing maternal and fetal hyperglycemia, resulted in mild hyperinsulinemia (Table 1). In both the models of hyperglycemia, adult and fetal liver and brain IR remained unchanged $(\sim 135$ and $\sim 125 \mathrm{kD})$ when compared to their respective controls. Further, the cleavage of sialic acid revealed the persistence of receptor heterogeneity between the liver and the brain in both the adult and fetus in response to hyperglycemia associated with either normo/hypo- or hyperinsulinemia.

Figure 3 demonstrates the IR in cultured neonatal rabbit brain cells, namely neurons and glial cells, whole brain membrane, and microvessel-enriched preparation in comparison with the neonatal rabbit liver IR. The rabbit whole brain (similar to the rat adult and fetal brain) migrated $\sim 10 \mathrm{kD}$ lighter than the liver 

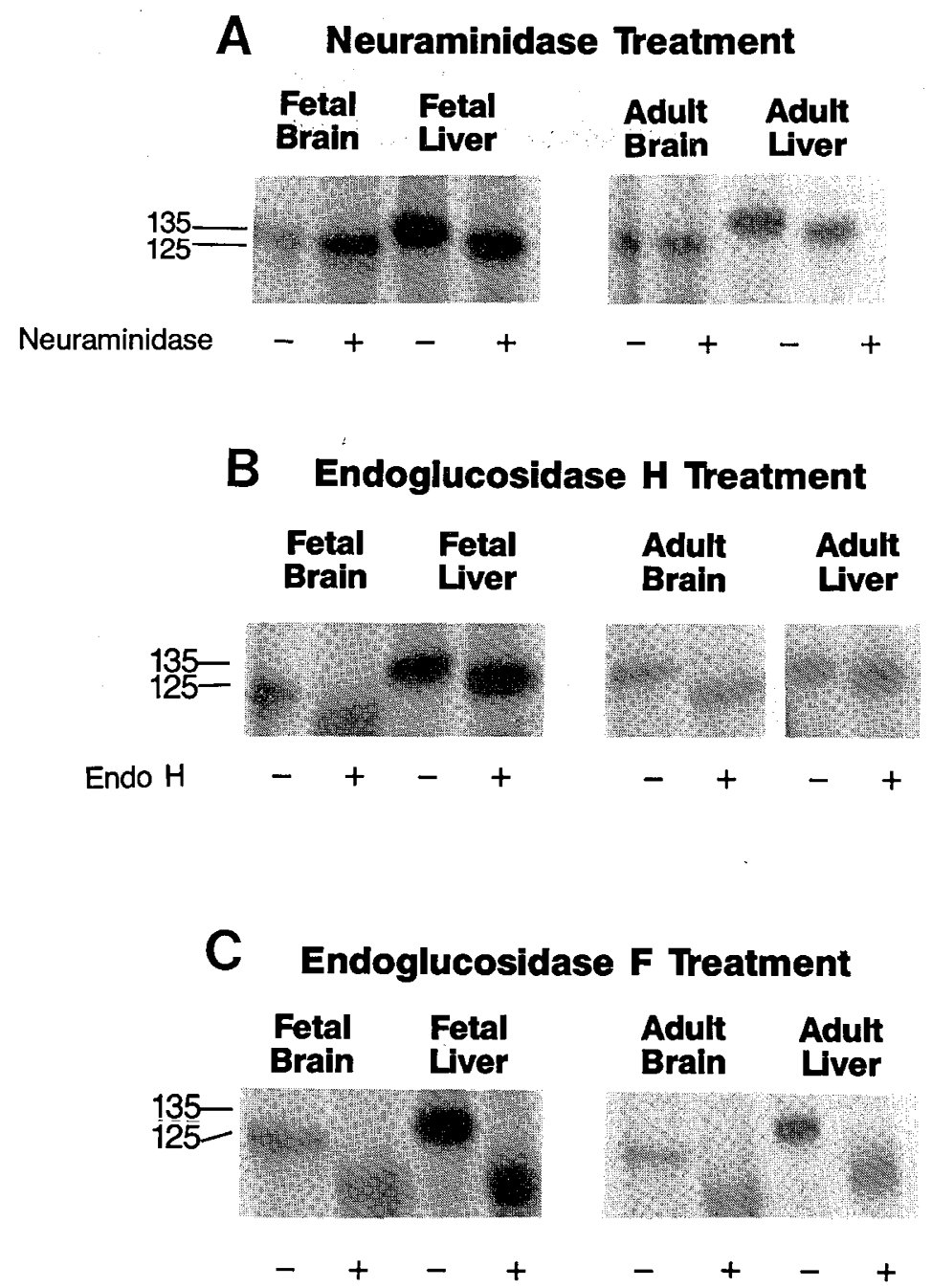

Fig. 2. Enzyme treatments: $A$, neuraminidase $(0.8 \mathrm{U})$ treatment cleaved the sialic acid altering the molecular mass of the fetal and adult liver IR from $\sim 135 \mathrm{kD}$ to $\sim 130 \mathrm{kD}$, but failed to alter the molecular mass of the fetal and adult brain IR $(\sim 125 \mathrm{kD}) ; B$, endoglucosidase $\mathrm{H}(0.023 \mathrm{IU})$ treatment altered the molecular mass of the fetal and adult brain IR from $\sim 125 \mathrm{kD}$ to $\sim 120 \mathrm{kD}$ and the fetal and adult liver IR from $\sim 135 \mathrm{kD}$ to $\sim 130 \mathrm{kD} ; C$, endoglucosidase $\mathrm{F}(10 \mu \mathrm{l})$ treatment enhanced the molecular mass of the fetal and adult liver IR from $\sim 135 \mathrm{kD}$ to $\sim 110 \mathrm{DK}$ and the fetal and adult brain IR from $\sim 125 \mathrm{kD}$ to $\sim 110 \mathrm{kD}$.

Table 1. Plasma glucose and insulin concentrations

\begin{tabular}{lcccc}
\hline Rats & $\begin{array}{c}\text { Glucose infused } \\
(n=5)\end{array}$ & $\begin{array}{c}\text { Controls } \\
(n=4)\end{array}$ & $\begin{array}{c}\text { Streptozotocin } \\
\text { treated } \\
(n=4)\end{array}$ & $\begin{array}{c}\text { Controls } \\
(n=5)\end{array}$ \\
\hline Mothers & & & & \\
Plasma glucose $(\mathrm{mg} / \mathrm{dl})$ & $368.8 \pm 78.64$ & $187 \pm 6.67$ & $317 \pm 11 \dagger$ & $109 \pm 3$ \\
$\quad$ Plasma insulin $(\mu \mathrm{U} / \mathrm{ml})$ & $26 \pm 0.41^{*}$ & $19 \pm 2.65$ & $4.7 \pm 0.47^{*}$ & $10.5 \pm 1.58$ \\
Fetuses & $155 \pm 25 \dagger$ & $42.5 \pm 2.5$ & $214 \pm 6 \dagger$ & $60 \pm 11.8$ \\
$\quad$ Plasma glucose $(\mathrm{mg} / \mathrm{dl})$ & $57.5 \pm 2.5 \dagger$ & $41.33 \pm 1.33$ & $40.6 \pm 2.8$ & $48.5 \pm 4.3$ \\
$\quad$ Plasma insulin $(\mu \mathrm{U} / \mathrm{ml})$ & & & \\
\hline
\end{tabular}

$* t$ test, $p<0.05$.

$\dagger t$ test, $p<0.01$.

IR $(\sim 135 \mathrm{kD})$. In comparison, the rabbit microvessel and neuronal IR were similar to that of the whole brain $(\sim 125 \mathrm{kD})$, whereas the glial IR was in between the brain and liver $(\sim 128$ $\mathrm{kD})$. Neuraminidase treatment revealed that the neonatal rabbit liver IR $(\sim 135 \mathrm{kD})$ was distinctly neuraminidase-sensitive, whereas the whole brain IR $(\sim 125 \mathrm{kD})$ was not, being similar to that of the rat. Additionally, rabbit neurons and microvessel IR which co-migrated with whole brain were neuraminidase-resistant. The glial cell IR, by contrast, migrated slightly higher than the whole brain and neurons $(\sim 128 \mathrm{kD})$ and was consistently neuraminidase-sensitive. The fetal rat brain microvessel IR, un- like the rabbit microvessel IR, comigrated with the liver IR, but distinct from the liver, was neuraminidase-resistant. The IR in mixed brain cells (neurons and glial cells) and the particulate rabbit brain following the isolation of microvessels was observed to migrate at $\sim 125 \mathrm{kD}$ and to be neuraminidase-resistant. Phase contrast microscopic examination of the latter fraction, however, revealed the presence of some microvasculature contamination along with the presence of cellular elements. Further experiments with Endo $\mathrm{H}$ and Endo $\mathrm{F}$, by contrast, resulted in similar increases in the mobility of the rabbit whole brain, microvessels, neurons, and glial cell IR, suggesting no major differences in the 


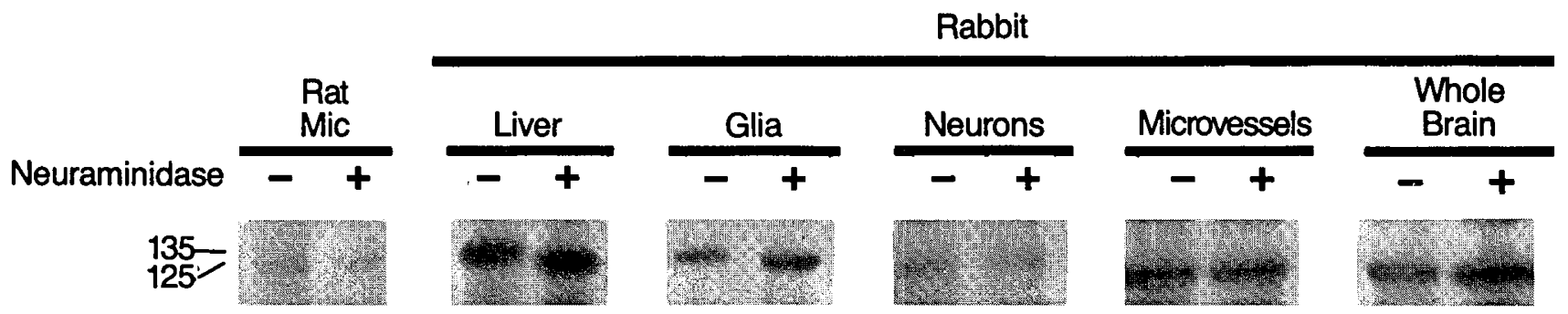

Fig. 3. Brain cell IR (alpha-subunit): The IR ( $\alpha$-subunit) of the fetal rat brain microvessels (mic) $(\sim 135 \mathrm{kD})$, newborn rabbit liver $(\sim 135 \mathrm{kD})$, glial cell $(\sim 128 \mathrm{kD})$, neurons $(\sim 125 \mathrm{kD})$, rabbit brain microvessels $(\sim 125 \mathrm{kD})$, and rabbit whole brain $(\sim 125 \mathrm{kD})$ are compared. Although neuraminidase $(0.8 \mathrm{U})$ treatment altered the mobility of the liver $(\sim 5 \mathrm{kD})$ and the glial cell $\mathrm{IR}(\sim 3 \mathrm{kD})$ mildly, it failed to alter the molecular mass of the rabbit whole brain, microvascular, neuronal, and fetal rat brain microvascular IR.

high mannose and complex oligosaccharide moieties in the various cell types.

\section{DISCUSSION}

The adult brain IR (21) has been demonstrated to have a decreased sialic acid content altering its mobility on SDS-PAGE by $\sim 10 \mathrm{KD}$ when compared to either tumorous brain tissue, such as the rat (34), and to certain human neuroblastoma cells (35), human glioma tissue (36), or to other organs, such as the liver (19), and to adipocytes (18). We have demonstrated that this difference between the brain and liver IR exists in the near term fetus as well. Recently, Brennan demonstrated slight differences in the sialic acid content of the IR between the early (16day) and late (20-day) fetal and adult rat brain IR. However, both the early and late fetal brain IR were lighter than the liver IR (37).

Similarly, studies in the chick embryo demonstrate that an IR deficient in sialic acid is present within the day 2 whole embryo and in the day 6 brain alone, suggesting that the "immature" receptor persists in the brain although differentiating in other tissues (22). In spite of this persistence of IR heterogeneity in the embryo, fetus, and adult, the fetal IR has been demonstrated to be distinct in other respects from the adult IR, for example, the IR in various fetal tissues is higher in number/mg (38-40), fails in vivo to down-regulate in response to high circulating insulin concentrations (8-10) and mediates an immature biologic response of insulin (41), specifically with regard to hepatic glucose to glycogen conversion (41). Similarly, the brain IR fails to down regulate in response to insulin both in vivo (5) and in vitro (6) and mediates a unique biologic effect of insulin within the central nervous system $(16,17)$. As suggested previously, if $\mathrm{N}$-linked glycosylation were responsible for down-regulation of the IR, one would expect to see similar glycosylation patterns in the fetal and adult brain IR and the fetal liver IR alone (adult liver IR being different), because these receptors uniformly express an inability to down-regulate in response to insulin. That these patterns are different suggests that the N-linked glycosylation of the IR is not solely responsible for the differences observed between the fetal and adult liver IR, and generally between the liver and brain IR.

Hyperinsulinemia has been shown to down regulate (42), whereas hypoinsulinemia up-regulates the IR in adult tissues (43). However, in the fetus, both high circulating insulin concentrations secondary to maternal diabetes (human, rabbit) $(8,10)$ and the normo/hypoinsulinemia seen in the offspring of a streptozotocin-diabetic rat mother, did not down-regulate tissue IR (9). In this report, we examined the effect of both high and low insulin concentrations associated with hyperglycemia on the Nlinked glycosylation of the adult and fetal brain and liver IR. Again, no differences were observed, suggesting that the $N$-linked glycosylation did not regulate the ability to down- or up-regulate the fetal and adult liver IR in response to varying insulin concentrations. One could argue that the brain IR N-linked glycosylation failed to change, possibly due to a lack of change in brain insulin and/or insulin receptor number (5). However, the liver, which is exposed to circulating insulin concentrations, did not demonstrate a change in response to hormonal perturbations as well, negating this theory.

Studies using specific brain cell types have demonstrated that the brain type IR is present in crude brain membranes from the whole brain and neurons alone (20), whereas glial cells possessed a peripheral or liver type of receptor. Here, we have confirmed this observation by demonstrating neuronal IR to be neuraminidase resistant, and the glial cell IR to be neuraminidase sensitive. Mixed brain cell cultures consisting primarily of glial and neuronal cells also demonstrated a neuraminidase resistance. In contrast to previous reports $(44,45)$, we have demonstrated the rabbit brain microvascular IR to comigrate with the brain IR and express neuraminidase resistance. By contrast, the rat brain microvascular IR while co-migrating with the liver IR, similar to that observed in the human and bovine species $(44,45)$, was neuraminidase resistant. The migratory pattern of the microvascular IR may be species specific; however, in the two species we examined, the IR was uniformly deficient in sialic acid. Whether similar sialic acid deficiency is seen in the human and bovine species previously studied is unknown at the present time. Our results demonstrate that both the neurons and the microvasculature IR are deficient in sialic acid, whereas the glial cell IR, like the liver, is neuraminidase sensitive, possessing varying amounts of sialic acid. Thus one can speculate that, while the sialic acid moiety is not associated with the receptor down-regulation phenomenon, it may be responsible for cell-cell interaction or specialized biologic functions specific to certain cell types alone.

In summary, similar to the adult, we have demonstrated the $\mathrm{N}$-linked glycosylation of the fetal rat brain to be distinct from the liver IR ( $\alpha$-subunit). Further, mild hyperinsulinemia or normo/hypoinsulinemia along with hyperglycemia had no effect on the interorgan heterogeneity of the IR N-linked glycosylation: Examination of specific brain cell types revealed that the neuronal and microvascular IR are deficient in sialic acid, conferring the "brain type" of receptor to the whole brain tissue, whereas the glial cell IR, which is intermediate in size (between the liver and brain), resemble the peripheral type (liver) of receptor by not being deficient in sialic acid. Although the receptor $\mathrm{N}$-linked glycosylation is not associated with the ability of the IR to downregulate in response to insulin, this posttranslational modification may contribute to a specific biologic function that needs delineation.

Acknowledgments. The authors acknowledge the technical assistance of P. Milner and D. Dudley and thank Ms. V. Shipp for her help in preparing this manuscript.

\section{REFERENCES}

1. Kasuga M, Hedo JA, Yamada KM, Kahn CR 1982 The structure of the insulin receptor and its subunits. J Biol Chem 257:10392-10399

2. Havrankova J, Roth J, Brownstein MJ 1979 Concentrations of insulin and insulin receptors in brain are independent of peripheral insulin levels. $J$ Clin Invest 64:636-642 
3. Kappy M, Sellinger S, Raizada MK 1984 Insulin binding in four regions of the developing rat brain. J Neurochem 42:198-203

4. Devaskar SU, Holekamp N, Devaskar UP 1986 Ontogenesis of the insulin receptor in the rabbit brain. Horm Res 24:319-327

5. Devaskar SU, Karycki L, Devaskar UP 1986 Varying brain insulin concentrations differentially regulate the fetal brain insulin receptor. Biochem Biophys Res Commun 136:208-219

6. Boyd Jr FT, Raizada MK 1983 Effects of insulin and tunicamycin on neuronal insulin receptor in culture. Am J Physiol 245:C283-C287

7. Ciaraldi T, Robbins R, Leidy JW, Thamm P, Berhanu P 1985 Insulin receptors on cultured hypothalamic cells: functional and structural differences from receptors on peripheral target cells. Endocrinology 116:2179-2185

8. Neufeld ND, Corbo L, Kaplan SA 1981 Plasma membrane insulin receptors in fetal rabbit lung. Pediatr Res 51:1081-1085

9. Neufeld ND, Corbo LM 1986 Insulin receptor development in normal and diabetic pregnancies. Diabetes 35:1020-1026

10. Neufeld ND, Kaplan SA, Lippe BM, Scott M 1978 Increased monocyte receptor binding of ${ }^{125}$ I-insulin in infants of gestational diabetic mothers. $J$ Clin Endocrinol Metabol 47:590-595

11. Schechter R, Holtzclaw L, Sadiq F, Kahn A, Devaskar S 1988 Insulin synthesis by isolated rabbit neurons. Endocrinology 123:505-513

12. Young WS 1986 Periventricular hypothalamic cells in the rat brain contain insulin mRNA. Neuropeptides 8:93-97

13. Duffy KR, Partridge WM 1987 Blood-brain barrier transcytosis on insulin in developing rabbits. Brain 420:32-38

14. Clarke DW, Boyd FT, Kappy MS, Raizada MK 1984 Insulin binds specific receptors and stimulates 2-deoxy-D-glucose uptake in cultured glial cells from rat brain. J Biol Chem 259:11672-11675

15. Clarke DW, Boyd FT Jr, Kappy MS, Raizada MK 1986 Insulin stimulates macromolecular synthesis in cultured glial cells from rat brain. Am J Physiol 249:C484-C489

16. Boyd FT Jr, Clarke DW, Muther TF, Raizada MK 1985 Insulin receptors and insulin modulation of norepinephrine uptake in neuronal cultures from rat brain. J Biol Chem 260:15880-15885

17. Puro DG, Agardh E 1984 Insulin-mediated regulation of neuronal maturation. Science 225:1170-1172

18. Heidenrich KA, Zahniser NR, Berhanu P, Brandenberg D, Olefsky JM 1983 Structural differences between insulin receptors in the brain and peripheral target tissues. J Biol Chem 258:8527-8530

19. Lowe W Jr, LeRoith D 1986 Insulin receptors from guinea pig liver and brain: Structural and Functional studies. Endocrinology 118:1669-1677

20. Lowe WL, Boyd FT Jr, Clarke DW, Raizada MK, Hart C, LeRoith D 1986 Development of brain insulin receptors: structural and functional studies of insulin receptors from whole brain and primary cell cultures. Endocrinology 119:25-35

21. Heidenrich KA, Brandenburg D 1986 Oligosaccharide heterogeneity of insulin receptors. Comparison of N-linked glycosylation of insulin receptors in adipocytes and brain. Endocrinology 118:1835-1842

22. Bassas L, dePablo F, Lesniak MA, Roth J 1987 The insulin receptors of chick embryo show tissue specific structural differences which parallel those of the insulin-like growth factor I receptors. Endocrinology 121:1468-1476

23. Djuricic BM, Kostic VS, Mrsulja BB 1983 Insulin increases entrance of 2deoxy-D- $\left({ }^{3} \mathrm{H}\right)$ glucose in isolated rat brain microvessels. Brain Res $275: 186-$ 188

24. Ktorza A, Girard J, Kinebanyan MF, Picon L 1981 Hyperglycemia induced by glucose infusion in the unrestrained pregnant rat during the three last days of gestation: Metabolic and hormonal changes in the mother and fetuses. Diabetologia 21:569-574
25. Nicolaidis S, Rowland N, Meile MJ, Marfaring-Jallat P, Pesez A 1974 A flexible technique for long term infusion in unrestrained rats. Pharmacol Biochem Behav 2:131-136

26. Bradford MM 1976 A rapid and sensitive method for the quantitation of microgram quantities of protein utilizing the principle of protein-dye binding. Anal Biochem 72:248-254

27. Goldstein GW, Wolinsky JS, Csejtey J, Diamond I 1975 Isolation of metabolically active capillaries from rat brain. J Neurochem 25:715-717

28. Sodoyez JC, Goffaux FS, Goff MM, Zimmerman AG, Arguilla ER $1975\left({ }^{127} \mathrm{I}\right)$ or carrier-free $\left({ }^{125} \mathrm{I}\right)$ moniodoinsulin: preparation, physical, immunological and biological properties and susceptibility to "insulinase" degradation. J Biol Chem 250:4268-4277

29. Chernausek SD, Jacobs S, Van Wyk JJ 1981 Structural similarities between receptors for somatomedin-C and insulin: analysis by affinity labeling. Biochemistry 20:7345-7350

30. Corfield AP, Veh RW, Wember M, Michalski J-C, Scharuer R 1981 The release of $\mathrm{N}$-acetyl and $\mathrm{N}$-glycolloyl-neuraminic acid from soluble complex carbohydrates and erythrocytes by bacterial, viral and mammalian sialidases. Biochem J 197:293-299

31. Tarentino AL, Maley F 1974 Purification and properties of an Endo-B-Nacetylglucosaminidase from Streptomyces griseus. J Biol Chem 249:811-817

32. Elder JH, Alexander S 1982 Endo-B-N-acetylglucosaminidase F: endoglycosidase from Flavobacterium meningosepticum that cleaves both high-mannose and complex glycoproteins. Proc Natl Acad Sci USA 79:4540-4544

33. Laemmli UK 1970 Cleavage of structural proteins during assembly of the head of bacteriophase T4. Nature 227:680-685

34. Heidenrich KA, Gilmore PR 1985 Structural and functional characteristics of insulin receptors in rat neuroblastoma cells. J Neurochem 45:1642-1648

35. Ota A, Shemer J, Pruss RM, Lowe WL Jr, LeRoith D 1988 Characterization of the altered oligosaccharide composition of the insulin receptor on neuralderived cells. Brain Res 443:1-11

36. Grunberger G, Lowe WL, McElduff A, Glick RP 1987 Insulin receptor of human cerebral gliomas. J Clin Invest 77:997-1005

37. Brennan WA Jr, 1988 Developmental aspects of the rat brain insulin receptor: loss of sialic acid and fluctuation in number characterize fetal development. Endocrinology 122:2364-2370

38. Devaskar S, Ganguli S, Devaskar U, Sperling MA 1982 Glucocorticoids and hypothyroidism modulate development of fetal lung insulin receptors. Am J Physiol 242:E385-E391

39. Sterman BM, Ganguli S, Devaskar S, Sperling MA 1983 Hypothyroidism and glucocorticoids modulate the development of hepatic insulin receptors. Pediatr Res 17:111-116

40. Neufeld ND, Scott M, Kaplan SA 1980 Ontogeny of the mammalian insulin receptor. Dev Biol 78:151-160

41. Sinha MK, Miller JD, Sperling MA, Suchy FJ, Ganguli S 1984 Possible dissociation between insulin binding and insulin action in isolated fetal rat hepatocytes. Diabetes 33:864-871

42. Olefsky JM 1976 Decreased insulin binding to adipocytes and circulating monocytes in obesity. J Clin Invest 57:1165-1172

43. Davidson MB, Kaplan SA 1977 Increased insulin binding by hepatic plasma membranes from diabetic rats: normalization by insulin therapy. $\mathrm{J}$ Clin Invest 59:22-30

44. Partridge WM, Eisenberg J, Yang J 1985 Human blood-brain barrier insulin receptor. J Neurochem 44:1771-1778

45. Roth AR, Morgan DO, Beaudoin J, Sara V 1986 Purification and characterization of the human brain insulin receptor. J Biol Chem 261:3753-3757

46. Haskell JF, Meezan E, Pillion DJ 1985 Identification of the insulin receptor of cerebral microvessels. Am J Physiol 248:E115-E125 